\title{
On a new Eurasian species of Dictyna Sundevall, 1833 (Aranei: Dictynidae), with taxonomic notes on poorly known Palaearctic Dictyna species
}

\author{
Новый евроазиатский вид Dictyna Sundevall, 1833 (Aranei: \\ Dictynidae), с таксономическими заметками о малоизвестных \\ палеарктических видах рода Dictyna
}

\author{
S.L. Esyunin ${ }^{1}$, A.N. Sozontov ${ }^{2}$ \\ С. $\Lambda$. Есюнин ${ }^{1}$, А.Н. Созонтов ${ }^{2}$
}

\begin{abstract}
${ }^{1}$ Perm State University, Bukireva Street 15, Perm, 614600 Russia. E-mail: Sergei.Esyunin@psu.ru
Пермский государственный университет, ул. Букирева 15, Пермь, 614600 Россия.

${ }^{2}$ Udmurt State University, Universitetskaya Str. 1/1, Izhevsk, 426034 Russia. E-mail: A.N.Sozontov@gmail.com

Удмуртский государственный университет, ул. Университетская, 1/1, Ижевск, 426034 Россия.
\end{abstract}

KEY WORDS: Dictynidae, spiders, new species, new combinations.

КЛЮЧЕВЫЕ СЛОВА: Dictynidae, пауки, новый вид, новые комбинации.

ABSTRACT. A new species Dictyna sinuata sp.n. $\left(O^{7}\right)$ is described from the steppe zone of Orenburg Area, Russia. This species belongs to the arundinacea species group and is closely related to the North American D. bostoniensis Emerton, 1888, from which it can readily be distinguished by the shape of conductor, the smaller body size, and the body coloration. New combinations are proposed for five species names (all ex. Dictyna): Nigma albida (O. Pickard-Cambridge, 1885) comb.n., Sudesna flavipes (Hu, 2001) comb.n., Bannaella lhasana (Hu, 2001) comb.n., Nigma nangquianensis (Hu, 2001) comb.n. and Brigittea varians (Spassky, 1952) comb.n. Dictyna xinjiangensis Song, Wang et Yang, 1985, syn.n., is synonymized with Brigittea varians (Spassky, 1952). The earlier synonymy is confirmed: Dictyna felis Bösenberg et Strand, $1906=$ Dictyna paitaensis Schenkel, 1953 syn.rev. Four species of Dictyna known from the females are to be treated as insertae sedis: "Dictyna" linzhiensis $\mathrm{Hu}$, 2001, "Dictyna" namulinensis $\mathrm{Hu}, 2001$, "Dictyna" tristis Spassky, 1952 and "Dictyna" zhangmuensis $\mathrm{Hu}$, 2001.

РЕЗЮМЕ. Новый вид Dictyna sinuata sp.n. $\left(\mathrm{O}^{7}\right)$ описывается из степей Оренбургской области (Россия). Вид принадлежит к группе arundinacea и близок к североамериканской D. bostoniensis Emerton, 1888 , от которой отличается формой кондуктора, меньшими размерами тела и окраской. Предложены новые комбинации для пяти видов (все бывшие Dictyna): Nigma albida (O. Pickard-Cambridge, 1885) comb.n., Sudesna flavipes (Hu, 2001) comb.n., Bannaella lhasana (Hu, 2001) comb.n., Nigma nangquianensis (Hu, 2001) comb.n. и Brigittea varians (Spas- sky, 1952) comb.n. Dictyna xinjiangensis Song, Wang et Yang, 1985 синонимизирован с Brigittea varians (Spassky, 1952). Подтверждена установленная ранее синонимия: Dictyna felis Bцsenberg et Strand, 1906 = Dictyna paitaensis Schenkel, 1953 syn.rev. Четыре вида Dictyna, известные по самкам, отнесены к insertae sedis: "Dictyna" linzhiensis Hu, 2001, "Dictyna" namulinensis $\mathrm{Hu}, 2001$, "Dictyna" tristis Spassky, 1952 и “Dictyna” zhangmuensis Hu, 2001.

\section{Introduction}

Dictyna Sundevall, 1833 is a large genus of the family Dictynidae numbering 188 valid species names [WSC, 2016]. The Palaearctic fauna of Dictyna contains 37 species, of which almost a half (17) remains known from the females only. There are 19 species of Dictyna in Russia [Mikhailov, 2013], with ten of them being found in the Urals [Esyunin, unpublished data]. In May 2015, as a result of the field trip to the steppe zone of Orenburg Region, three adult males of a new Dictyna species were collected. This new species is described and illustrated in the present paper. We have also analyzed the original descriptions of 17 Palaearcrtic Dictyna species known from the females and presented taxonomic conclusions based on this analysis.

SEM micrographs were made by means of a Hitachi TM3000 SEM microscope with BSE (back-scattered electrons) at the Perm State University. The terminology of the dictynid palp morphology follows Marusik, Penney [2010]. The following abbreviations are used in the text: ALE - anterior lateral eyes; AME anterior median eyes; PLE — posterior lateral eyes; PME - posterior median eyes. All measurements are 


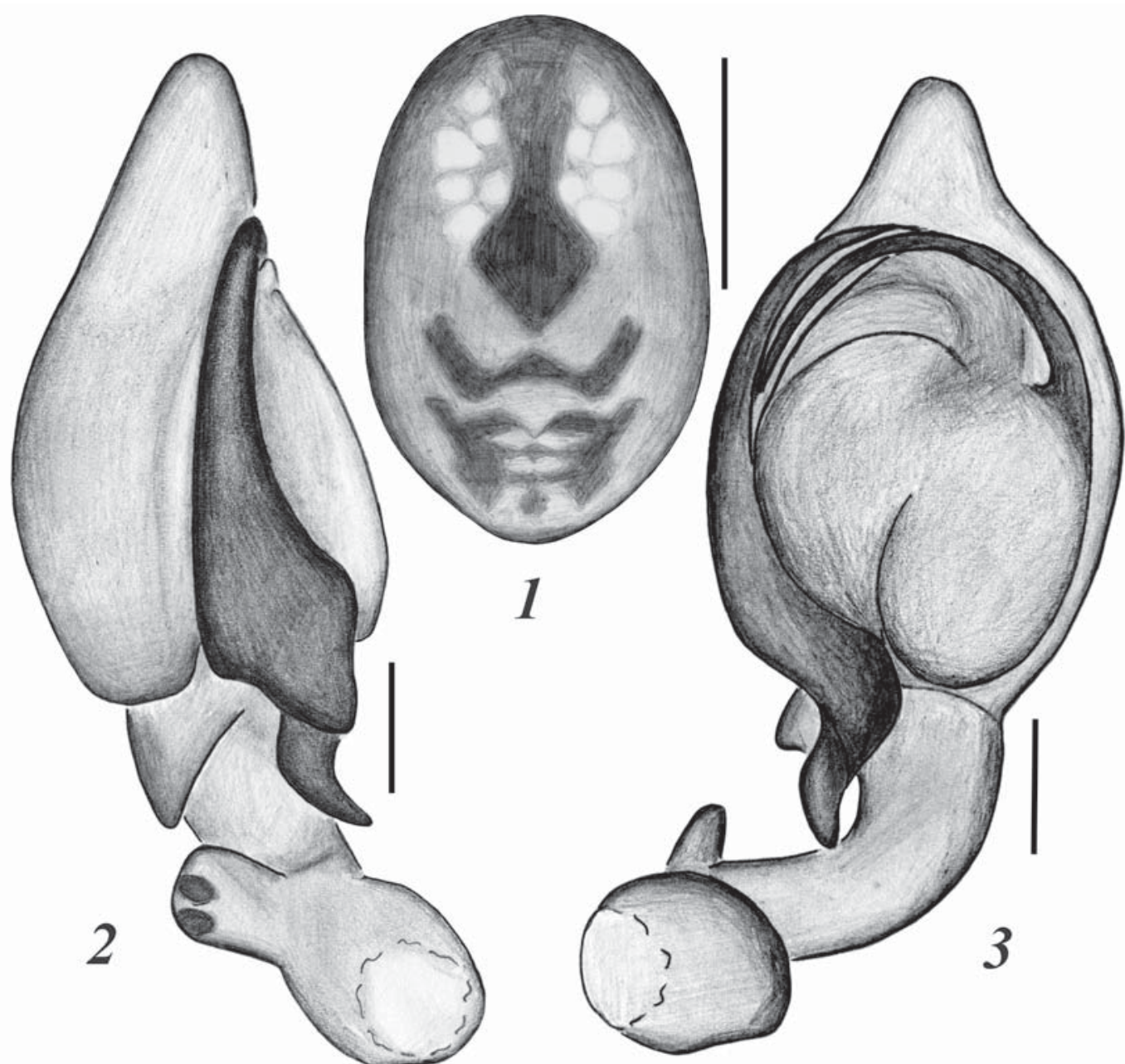

Figs 1-3. Abdomen and palp of Dictyna sinuata sp.n. (paratype). 1 - abdomen, dorsal view, scale 0.5 mm.; $2-3$ - palp, lateral and ventral views, scale $0.1 \mathrm{~mm}$.

Рис. 1-3. Брюшко и пальпа Dictyna sinuata sp.n. (паратип). 1 - брюшко, дорзально, масштаб 0,5 мм; 2, 3 - пальпа, вентрально и латерально, масштаб 0,1 мм.

given in millimeters. The holotype and two paratypes of the new species are deposited in the Zoological Museum of the Moscow State University (ZMMU, K.G. Mikhailov) and the Zoological Museum of the Perm State University (PSU, S.L. Esyunin).

\section{Description}

\section{Dictyna sinuata sp.n.}

Figs 1-7.

Types. Holotype $\sigma^{7}$ (ZMMU) from Russia, Orenburg Area, Svetlyi Distr., c. $10 \mathrm{~km} \mathrm{~N}$ of Pervomayskiy Vil., the "Ashchisayskaya steppe' division of the Orenburg Reserve, $50^{\circ} 58^{\prime} \mathrm{N}, 61^{\circ} 09^{\prime} \mathrm{E}$, steppe, 6.V.2015 (A.N. Sozontov). — Paratypes: $10^{7}$ (ZMMU), $1 \mathrm{O}^{7}$ (PSU), together with the holotype.

ETYMOLOGY. The species name is derived from the Latin word "sinuatus" meaning sinuate.

DESCRIPTION. Male. Spider is small, total length 2.18 (2.05-2.30). Carapace length 0.95 (0.90-0.95), width 0.7 (0.7-0.7). Carapace pear-shaped, brown, with dark brown edges and five longitudinal rows of white hairs in the middle. Chelicera 0.4 long, brown, with a medial furrow in its inner margin, curved shape at the anterior side and poriferous microstructure at its basal part (Fig. 6). Cheliceral furrow curved backward, with 3 teeth on the promargin (Fig. 7). Labium trapezoid, its maximal width at the base is equal to its length. Maxillae elongated, width/length ratio 0.45 , brown or yellow-brown, with a white tip. Sternum roundish, brown. Legs yellow-brown, with blackened femora. Abdomen white dorsally, with a black pattern of longitudinal median spots in its anterior half and transverse thin stripes in its posterior half (Fig. 1). Cardiac mark as an extended rhomb. Thin lateral stripes bent anteriorly. Abdominal sides black. Venter white, with a broad median band. Cribellum transverse. Spinnerets brown.

Eyes field transverse, its length 2.2 times longer than its width. Eye sizes and interdistances: AME 0.04, PME 0.05, PLE 0.05, ALE 0.05; AME-AME 0.08, PME-PME 0.08, AME-PME 0.07. Medial eyes field 

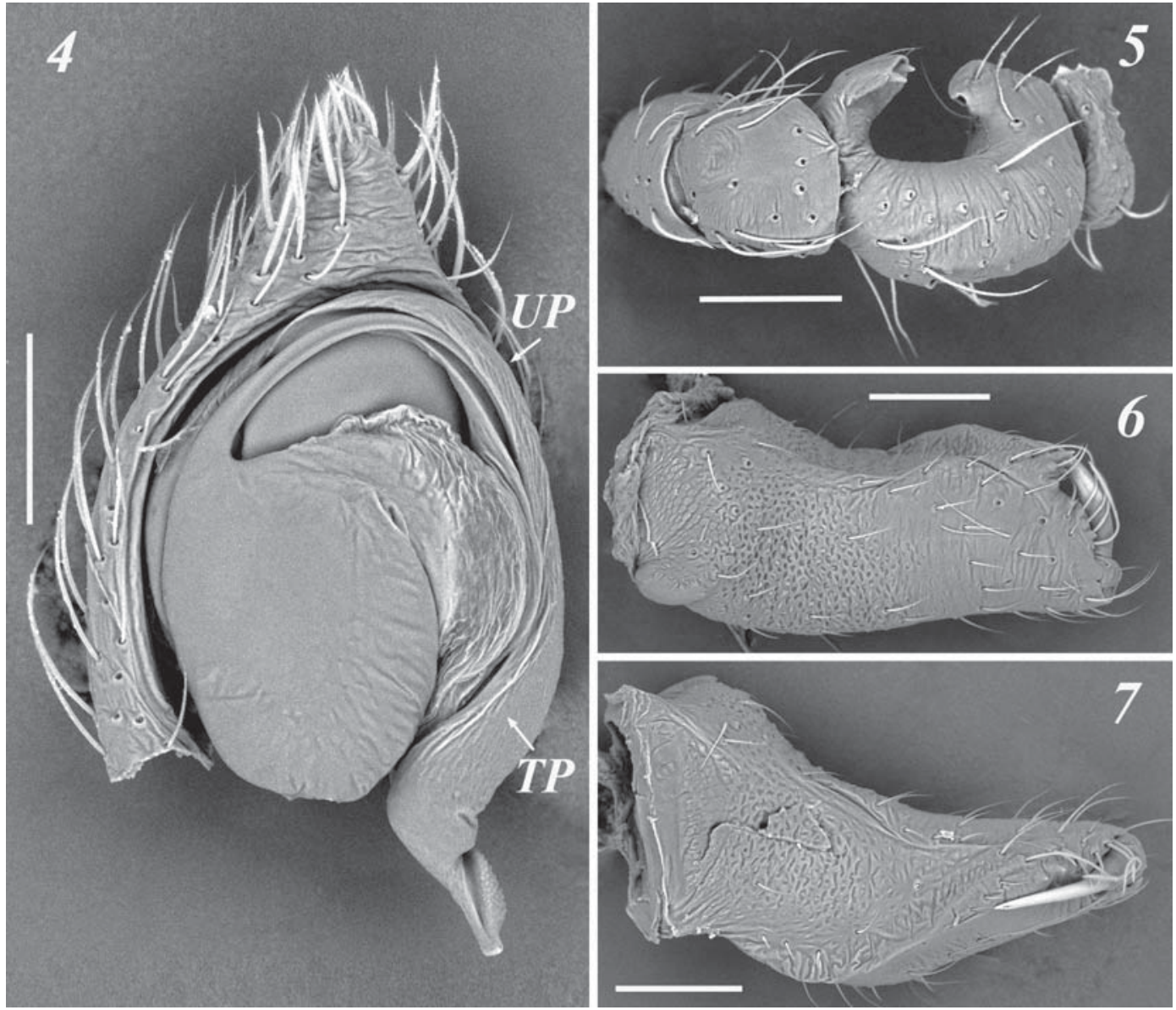

Figs 4-7. Male palp and chelicera of Dictyna sinuata sp.n. (paratype). 4 - bulbus, ventral view; 5 - palp tibia, dorsal view; 6-7 chelicerae, interiorly and internally. Scale $0.1 \mathrm{~mm}$. Abbreviations: $T P$ - terminal part of the conductor, $U P$ - upper part of the conductor.

Рис. 4-7. Хелицера и пальпа самца Dictyna sinuata sp.n. (паратип). 4 - бульбус, вентрально; 5 - голень пальпы, дорзально; 6, 7 - хелицера, снаружи и изнутри. Масштаб 0,1 мм. Сокращения: $T P$ - терминальная часть кондуктора, $U P$ - верхняя часть кондуктора.

almost square: length 0.14 , width 0.14 anteriorly and 0.15 posteriorly.

Leg formula: I, II, IV, III. Leg measurements are given in the Table:

\begin{tabular}{|l|c|c|c|c|c|}
\hline Leg & Femur & Patella+Tibia & Metatarsus & Tarsus & Total length \\
\hline I & 0.87 & 1.02 & 0.60 & 0.42 & 2.91 \\
& $(0.80-0.90)$ & $(0.95-1.05)$ & $(0.55-0.65)$ & $(0.40-0.45)$ & $(2.70-3.05)$ \\
\hline II & 0.72 & 0.8 & 0.5 & 0.35 & 2.37 \\
& $(0.65-0.75)$ & $(0.75-0.85)$ & $(0.45-0.55)$ & $(0.35-0.35)$ & $(2.20-2.50)$ \\
\hline III & 0.52 & 0.58 & 0.42 & 0.30 & 1.82 \\
& $(0.45-0.55)$ & $(0.50-0.65)$ & $(0.35-0.45)$ & $(0.30-0.30)$ & $(1.60-1.95)$ \\
\hline IV & 0.65 & 0.73 & 0.52 & 0.30 & 2.20 \\
& $(0.60-0.70)$ & $(0.65-0.80)$ & $(0.50-0.55)$ & $(0.30-0.30)$ & $(2.05-2.35)$ \\
\hline
\end{tabular}

The bulb conformation is typical for the genus (Figs 2-4): embolic base is situated laterally; embolus thin, arc-shaped; the upper part of conductor (sensu Marusik \& Penney [2010]) is arc-shaped and procurved, forming a membranous groove; the terminal part of conductor is weakly twisted around its axis and directed backwards; the tip of the terminal part of conductor is simple, with multiple denticles situated at its external edge (Fig. 4); the palpal tibia is modified, with a deep socket (Fig. 2-3, 5); a pair of ctenidia present at the tip of the posterior appendage (Fig. 5).
Female is unknown.

TAXONOMIC REMARKS. A notable modification of the palpal tibia, such as a deep socket (Fig. 5), is the unique diagnostic feature of $D$. sinuata sp.n. which is absent from the males of all the known Palaearctic Dictyna species. To date, a more or less developed lateral socket of the palpal tibia has been described for a few North American species of the foliacea ( $D$. foliacea (Hentz, 1850)) and arundinacea ${ }^{1}(D$. bostoniensis Emerton, 1888, D. brevitarsa Emerton, 1915, D. crosbyi Gertch et Mulaik, 1940) species groups only (see Chamberlin, Gertsch [1958]).

The male of $D$. sinuata sp.n. differs from those of the foliacea species group in the absence of a rounded spur situated at the basal part of chelicerae. Two species of the arundinacea group (D. brevitarsa and $D$. crosbyi) can readily be distinguished from $D$. sinuata sp.n. by the presence of an unmodified posterior (basal) rim of the palpal tibial socket.

The name "arundinacea-group" was proposed by Lehtinen [1967]; there is another name for the same species group - brevitarsus - proposed by Chamberlin \& Gertsch [1958]. 
By the shape of palpal tibia, the male of $D$. sinuata sp.n. is most similar to that of D. bostoniensis, but differs in the conformation of conductor. In the latter species, the upper part of the conductor (sensu Marusik, Penney [2010]) is short, not reaching the middle part of the cymbium, and the terminal part possesses a tooth-shape projection (absent in $D$. sinuata). Additional differences between these two species include: 1) the total length of the new species (2.05-2.30) is significantly smaller than that of the American one (2.5-4.5), and the size ranges do not overlap; 2) the sternum and the carapace are orange in $D$. bostoniensis and brown in D. sinuata; 3 ) the carapace of the American species has dark radial lines that are absent from D. sinuata; 4) the cardiac mark is tridental in D. bostoniensis, and rhombshaped in D. sinuata; 5) the venter is light, often having dark speckles by its edges in D. bostoniensis, whereas that of $D$. sinuata is white, with a dark medial band.

DISTRIBUTION. The type locality only.

\section{Taxonomic notes on poorly known Dicty-} na species

As mentioned above, 17 Palaearcrtic species of Dictyna remain known from the females only. A careful analysis of their original descriptions has allowed us to come to the following taxonomic conclusions, all of which are in good evidence that none of these species could represent an unknown female of the new species described herein.

\section{New combinations and synonymy}

The following five Dyctina species are to be transferred to other genera.

1. Nigma albida (O. Pickard-Cambridge, 1885), comb.n.

COMMENTS. Pickard-Cambridge [1885: 29] wrote that this species, which was described from western China (from between Yangi Hissar Town, Xinjiang Province, China and "Sirikol River"), "belongs to the Dictyna variabilis (Koch) [sic! - S.E.] group". According to WSC [2016], Dictyna variabilis C.L. Koch, 1836 is a junior synonym of Nigma flavescens (Walckenaer, 1830), the type species of the genus Nigma Lehtinen, 1967. The latter genus includes 13 species that are primarily distributed in the subtropical areas of the West and Central Palaearctic Region. Based on the specimens from Lahore (Pakistan), Dyal [1935: fig. 79] redescribed and illustrated the female of $N$. albida. In our opinion, the female of $N$. albida described by Dyal [1935] resembles that of $N$. conducens (O. Pickard-Cambridge, 1876) from North Africa (cf. Lehtinen [1967: fig. 329]), but differs from it in having the yellow carapace (dark in $N$. conducens).

\section{Sudesna flavipes (Hu, 2001), comb.n.}

COMMENTS. According to Hu [2001: 621], Dictyna flavipes $\mathrm{Hu}, 2001$ described from Xinjiang Province of China "is allied" to Emblyna wangi (Song et Zhou, 1985). However, the endogyna conformation of $S$. flavipes does not correspond to that of the genus Emblyna Chamberlin, 1948. Based on the original figures by $\mathrm{Hu}$ [2001: figs 8-19], the female possesses all the diagnostic characters of the genus Sudesna Lehtinen, 1967 (see Zhang, Li [2011]): viz., (1) the copulatory openings are situated anteriorly and widely separated from each other - the distance between them is 1.5 times longer than their diameter; (2) the tube-like copulatory ducts; and (3) the spermathecal heads are situated laterally. $S$. flavipes is most similar to $S$. circularis Zhang et Li, 2011 described from Yunnan Province of China, but can be distinguished by the following characters: (1) the ovoid spermatheca are not inclined to each other (inclined anteriorly in $S$. circularis); (2) a single convolution of the copulatory duct (two convolutions in $S$. circularis); and (3) this species is larger, with its total length of $3 \mathrm{~mm}$ ( $S$. circularis smaller, the total length 1.6-2.0 $\mathrm{mm}$ ).

3. Bannaella lhasana (Hu, 2001), comb.n.

COMMENTS. Dictyna lhasana Hu, 2001 was described from Xizang Autonomous Region of China. $\mathrm{Hu}$ [2001: 621] wrote that "this new species resembles Dictyna xinjiangensis". However, based on the original description [Hu, 2001: figs 8-21], this species should be assigned to the genus Bannaella Zhang et Li, 2011 recently described from China, because it has got the triangle, extending backwards epigyne and the S-shaped copulatory ducts. From both Bannaella species known from Yunnan Province of China, B. lhasana differs in having the widely separated epigynal fossae (close to each other both in B. sinuata Zhang et Li, 2011 and in B. tibialis Zhang et Li, 2011).

4. Nigma nangquianensis (Hu, 2001), comb.n.

COMMENTS. Hu [2001: 622] wrote that this species "resembles" Nigma flavescens (Walckenaer, 1830). We are of the same opinion, because the endogyne has got: (1) the )(-shaped "receptacules", and (2) the sacshaped structures that are typical of Nigma. N. nangquianensis differs from all other Nigma species known to us in having the transverse epigynal plate (the elongated plate in other species).

5. Brigittea varians (Spassky, 1952), comb.rev. = Dictyna xinjiangensis Song, Wang et Yang, 1985, syn.n.

COMMENTS. Dictyna varians Spassky, 1952 was described from Tajikistan, Kazakhstan and Rostov Region of Russia. It was synonymized by Lehtinen [1967: 252] with Brigittea latens (Fabricius, 1775). Having mentioned the "uncertain synonymy", Brignoli [1983: 511] proposed a new combination Brigittea varians (Spassky, 1952), which is not currently accepted by the WSC [2016]. We support Brignoli's view, because 

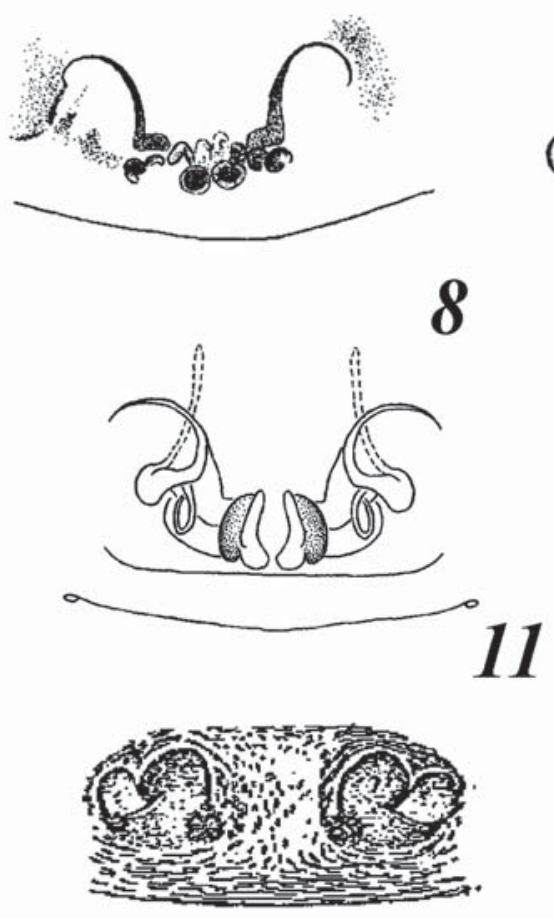

15

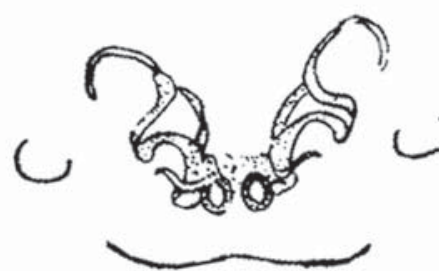

9

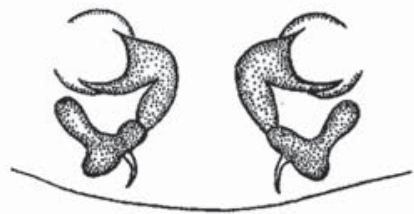

12

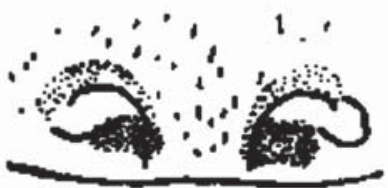

16
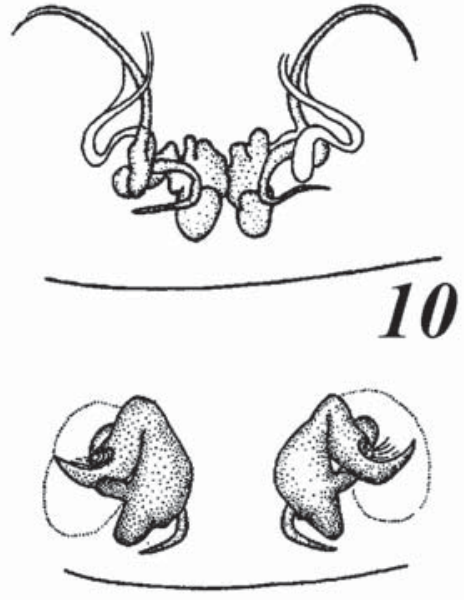

13

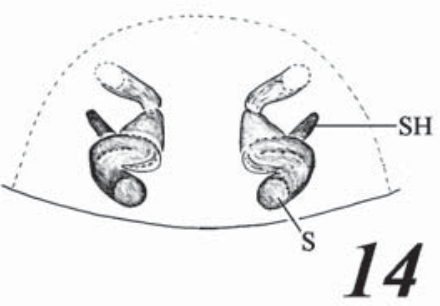

Figs 8-16. Epigynes of some dictynid species: Dictyna felis Bösenberg et Strand, 1906 (8-11), "Dictyna" zhangmuensis Hu, 2001 (12), Sudesna hedini (Schenkel, 1936) (13), S. digitata Zhang et Li, 2011 (14) and Brigittea varians (Spassky, 1952) (15, 16). Abbreviations: S - spermatheca; SH - spermathecal head. Figures were borrowed from the following publications: 8 - Schenkel, 1953 : fig. 5c; as Dictyna paitaensis Schenkel, 1953; 9 - Zhu et Shi, 1985: fig. 45c; 10 — Song et Lu, 1985: fig. 3a, as Dictyna foliicola Bösenberg et Strand, 1906; 11 - Yin et al., 2011: fig.494c; 12 - Hu, 2001: fig. 8-27.3; 13 - Song et Lu, 1985: fig. 4b; 14 - Zhang et Li, 2011: fig. 11B; 15 - Spassky, 1952: fig. 4; 16 - Song et al., 1985: fig. 4, as Dictyna xinjiangensis Song, Wang et Yang, 1985.

Рис. 8-16. Эпигины некоторых видов диктинид: Dictyna felis Bцsenberg et Strand, 1906 (8-11), “Dictyna” zhangmuensis Hu, 2001 (12), Sudesna hedini (Schenkel, 1936) (13), S. digitata Zhang et Li, 2011 (14), Brigittea varians (Spassky, 1952) (15-16). Сокращения: S - сперматека; SH - «головка» сперматеки. Использованы иллюстрации из следующих публикаций: 8 Schenkel, 1953: fig. 5c как Dictyna paitaensis Schenkel, 1953; 9 - Zhu, Shi, 1985: fig. 45c; 10 - Song, Lu, 1985: fig. 3a, как Dictyna foliicola Bösenberg et Strand, 1906; 11 - Yin et al., 2011: fig.494c; 12 - Hu, 2001: fig. 8-27.3; 13 — Song, Lu, 1985: fig. 4b; 14 — Zhang, Li, 2011: fig. 11B; 15 - Spassky, 1952: fig. 4; 16 — Song et al., 1985: fig. 4, как Dictyna xinjiangensis Song, Wang et Yang, 1985.

Spassky [1952: 202] pointed out that this species had got the "bilobate cribellum", the character that is diagnostic of the genus Brigittea Lehtinen, 1967 [Marusik et al., 2015]. The widely separated epigynal fossae (i.e., the distance between them is about the same as their diameter) are known from two Brigittea species: B. innocens (O. Pickard-Cambridge, 1872) and B. latens (Fabricius, 1775). B. varians can easily be distinguished from both by its abdominal coloration, which is "whitish and bears four wide brown spots situated longitudinally" (see Spassky [1952: 202]); the brownblack pattern in $B$. innocens and "from completely black to whitish with black folium" in B. latens [Marusik et al., 2015: 138].

Dictyna xinjiangensis Song, Wang et Yang, 1985, of which the generic assignment remained uncertain, is very close to $B$. varians by its epigyne conformation. The authors of the original description [Song et al., 1985: 25] were of the opinion that "this new species is closely allied to Dictyna hedini Schenkel". However, this species was not mentioned as a member of the genus Sudesna by Zhang \& Li [2011]. Furthermore, the species has got the "head region high" [Song et al., 1985: 25], which is not characteristic of the genus Sudesna, but well corresponds to the structure of the head region in $B$. latens, the type species of the genus Brigittea. Both the somatic characters and the structure of the epigyne (Figs 15, 16) in B. varians and $D$. xinjiangensis are virtually identical: (1) carapace size: 1.12 long, 0.88 wide and 1.13 long, 0.84 wide, respectively; (2) "carapace brown ... head region bears whitish hairs" [Spassky, 1952: 202] and "carapace reddish brown. Head region ... with ... white hairs" [Song et al., 1985: 25]; (3) "the width of epigynal fossae is two times longer than their length"; (4) "a curved chitinous fold branches out the outer edge of fossae, running into the fossae and reaching almost the middle of their length"; (5) "there is a small brown spot seen at the rear-inner edge of each fossa". Therefore, in our opinion, it is safe to conclude that $D$. xinjiangensis Song, 
Wang et Yang, 1985 is to be considered a junior synonym of B. varians (Spassky, 1952).

6. Dictyna felis Bösenberg et Strand, $1906=$ Dictyna paitaensis Schenkel, 1953, syn.rev.

COMMENTS. Lehtinen [1967: 229] argued that $D$. paitaensis was a junior synonym of $D$. felis. Brignoli's opinion [1983: 512] that it was an "uncertain synonymy" is hardly justified, because (1) the type locality of D. paitaensis (close to Beijing, China) lies within the known range of $D$. felis, of which the western limit runs along the line Inner Mongolia - Hebei - Hubei - Hunan Provinces of China [Yin et al., 2012], eastward to Japan [Chikuni, 1989], southward to Hunan Province of China north to Maritime Province of Russia [Dunin, 1984]; (2) the males of D. felis, which have been wellillustrated by many authors from Japan, Korea, Russia and China, show the identical structure of copulatory organs across the species range; (3) based on the Chinese authors [e.g., Song, 1987; Zhang, 1987], who illustrated both sexes collected together, the epigynal conformation of D. felis (Figs 9-11) only insignificantly differs from that of $D$. paitaensis (Fig. 8), while the main characteristics are identical: (a) two widely separated fossae, (b) the distance between fossae twice as long as the fossa diameter in the anterior (restricted by the chitinous fold) part of the epigyne, (c) "receptacles" are small and round, situated at the lower edge of the fossae; (4) somatic characters of both species overlap:

\begin{tabular}{|l|c|c|}
\hline Character & felis & paitaensis \\
\hline Body length & $2.5-5.0 \mathrm{~mm}$ & 4.6 (but carapace 2.2 + abdomen $2.6=$ total 4.8$) \mathrm{mm}$ \\
\hline Carapace colour & dark brown & brown \\
\hline Sternum colour & brown & brown \\
\hline
\end{tabular}

Therefore, in our opinion, Dictyna paitaensis is indeed a junior synonym of Dictyna felis, as was originally stated by Lehtinen [1967].

D. felis is very close to Dictyna foliicola Bösenberg et Strand, 1906 having a similar range (Maritime Province of Russia, central and eastern China, Korea, Japan). The males of the latter species are reliably separable by the longer cymbium and conductor. According to [Yin et al., 2012: 976], the female copulatory ducts are twisted and very complex: the "receptacular organ arranged in transverse rectangle" in D. foliicola, whereas in $D$. felis the copulatory duct with a single loop in the middle; the endogyne of both species is $\mathrm{V}$ shape.

\section{Species insertae sedis}

Based on the original descriptions, four Dictyna species, which are still known from the females only, are to be treated as insertae sedis.

\section{1. "Dictyna" linzhiensis $\mathrm{Hu}, 2001$.}

COMMENTS. Hu [2001: 622] wrote that "this new species resembles Dictyna civica (H. Lucas)", but we failed to find any similarity in the conformation of the endogyne of this species with the congeners of the genus Brigittea. Both the large epigynal fossae, with a clear edge and structured bottom (see Chamberlin, Gertsch [1958]), and the small spermatheca are characteristic of the genus Tricholathys Chamberlin et Ivie, 1935. The only Palaearctic member of this genus $-T$. relicta Ovtchinnikov, 2001 - was described from Kyrgyzstan [Ovtchinnikov, 2001]; it is twice as large as "Dictyna" linzhiensis and has got a different abdominal colour pattern and cheliceral dentation.

2-3. "Dictyna" namulinensis Hu, 2001 and "Dictyna" zhangmuensis $\mathrm{Hu}, 2001$

COMMENTS. Both species were described from China and, in our opinion, were mistakenly compared with Nigma flavescens. The conformation of the epigyne and the endogyne of "D." namulinensis (see Hu [2001: figs 8-24] does not correspond to those of true Dictyna, because the latter is characterised by two epigynal fossae and the V-shaped configuration of the endogyne. By the presence of the singular, central epigynal depression, "D." namulinensis is similar to representatives of the genus Ajmonia Caporiacco, 1934, but yet its endogyne shows a different structure, with a longitudinal rather than transversal arrangement of endogynal elements. Unfortunately, based solely on the original figures, it is impossible to analyze individual structures of the endogyne and thus to undertake a comparative analysis. A generic assignment of species therefore remains uncertain.

“D." zhangmuensis (see [Hu, 2001: figs 8-27] differs from representatives of the true Dictyna, as well as from the genus Nigma, in having the widely separated epigynal fossae and receptacles (Fig. 12; close or in contact in both compared genera). With certain assumptions, such the structure of epigyne and endogyne are known in the genus Sudesna, namely in $S$. hedini (Schenkel, 1936) and S. digitata Zhang et Li, 2011 (Figs 13, 14). The necessary assumption is related to the V-shaped receptacles shown by Hu (Fig. 12), which are to be interpreted as two structures: the oval spermathecae inclined to the median line of the epigyne and the spermathecal heads situated at the right angle to the spermathecae. The epigyne of " $D$." zhangmuensis is somewhat similar to that of $S$. hedini, but can be distinguished by the following character: the "spermathecal heads" (= the external part of the V-shaped spermatheca shown in Hu's figure, Fig. 12) is large, nearly equal to the width of "spermatheca" itself (the inner part of the V-shaped spermatheca as shown in Hu's figure); in $S$. hedini, the spermathecal heads are smaller than the spermatheca width. However, the real generic assignment of this species remains uncertain.

\section{4. "Dictyna" tristis Spassky, 1952}

COMMENTS. The species was described from Tajikistan and then synonymized with Nigma flavescens by Lehtinen [1967: 252]. Brignoli [1983: 516] mentioned this synonymy as "uncertain" and proposed a new combination Nigma tristis (Spassky, 1952). The latter is indeed mistaken, as the original description 
clearly points to the undivided cribellum [Spassky, 1952: 2002]. Abdominal pattern is typical of the genus Dictyna, but the conformation of the epigyne is rather atypical. Based on the original description, the epigyne consists of "two deep bud-shaped fossae ... facing forward". It is impossible to define the generic assignment of this species without an examination of its endogyne, and thus the species' status is to be treated as inserta sedis.

Four poorly known Dictyna species, which are still known from the females, were described from the territories lying far away from the type locality of the new species describes herein and, in our opinion, could not belong to this species. D. ignobilis Kulczyński, 1895 is known from Moldova and Armenia. D. procerula Bösenberg et Strand, 1906 is restricted to Japan. The following two species are known from Central Asia. D. cronebergi Simon, 1889 was described from Turkmenistan; it is small, with total length of $2 \mathrm{~mm}$. Its carapace yellow-red, abdomen of redbrick colour and covered with niveous hairs. D. uzbekistanica Charitonov, 1946 was described from Uzbekistan, and it is larger than our species, with the total length of $4 \mathrm{~mm}$. Its carapace orange-red, covered with white hairs, legs yellow, and abdomen dark yellow. Besides, the latter species has got the spiral spermathecae with a large number of convolutions, which is not typical of either the arundinacea species group, or the genus Dictyna on the whole.

Two Dictyna species were described from single females from Buryatia (eastern Siberia, Russia) and from non-steppe habitats [Danilov, 1994, 2000]: $D$. dunini Danilov, 2000 inhabiting meadows and mixed forests and D. sotnik Danilov, 1994 inhabiting the pine forest.

Of the steppe habitats of West and South Siberia are known two Dictyna species described from the females: D. dahurica Danilov, 2000 and D. uvs Marusik et Koponen, 1998. The main morphological characters of both species and our new species are given in the Table:

\begin{tabular}{|l|l|l|l|}
\hline Character* & $\begin{array}{l}\text { Dictyna sinuata } \\
\text { (male) }\end{array}$ & $\begin{array}{l}\text { Dictyna dahurica } \\
\text { (female) }\end{array}$ & $\begin{array}{l}\text { Dictyna uvs } \\
\text { (female) }\end{array}$ \\
\hline $\begin{array}{l}\text { Abdomen } \\
\text { colour }\end{array}$ & white & $?$ & ochre \\
\hline $\begin{array}{l}\text { Abdomen } \\
\text { colour pattern }\end{array}$ & $\begin{array}{l}\text { longitudinal median } \\
\text { spots anteriorly; } \\
\text { transverse thin stripes } \\
\text { posteriorly }\end{array}$ & $\begin{array}{l}\text { typical pattern for } \\
\text { the } \text { major } \text { group }\end{array}$ & $\begin{array}{l}\text { with a } \\
\text { rectangular } \\
\text { brownish sport }\end{array}$ \\
\hline Spot's apex & diamond-shaped & with a 'crown' & rectangular \\
\hline
\end{tabular}

$D$. sinuata readily differs from both in its abdominal colour pattern, and from $D . u v s$ also in its general body coloration.

ACKNOWLEDGMENTS. The authors are grateful to the staff of the Orenburg State Reserve for their help with organization of fieldworks: viz., R.T. Bakirova, O.V. Soro-

* The characters that are subject to sexual dimorphism are not included; as compared to the females, Dictyna males are usually smaller, with the darker carapace and the more conspicuous head. ka, I.I. Raseyikin, V.A. Arzhanukhin, and to the Head of the Zoological Museum of the Perm State University, A.V. Grischenko, for allowing us to use their SEM facilities. Special thanks go to Dmitri V. Logunov (Manchester, UK) for commenting on the manuscript and for editing the English of the final draft. The presented study was supported by the RFBR, project \# 14-04-31178.

\section{References}

Brignoli P.M. 1983. A catalogue of the Araneae described between 1940 and 1981. Manchester University Press. 755 p.

Chamberlin R.V., Gertsch W.J. 1958. The spider family Dictynidae in America north of Mexico // Bulletin of the American Museum of Natural History. Vol. 116. P.1-152.

Chikuni Y. 1989. Pictorial Encyclopedia of Spiders in Japan. Tokyo: Kaisei-sha Publishing Co. 310 p.

Danilov S.N. 1994. [Cribellate spiders (Aranei, Cribellatae) of Transbaicalia] // Entomologicheskoe Obozrenie. Vol.73. P.200209 [in Russian].

Danilov S.N. 2000. New data on the spiders of the family Dictynidae (Araneae) from Siberia // Ekológia (Bratislava). Vol.19. Suppl.3. P.37-44.

Dunin P.M. 1984. [Materials on the spider fauna from the Far East (Arachnida, Aranei). 2. Section Cribellatae] // Fauna i ekologia nasekomykh yuga Dalnego Vostoka. Vladivostok: DVTs AN SSSR. P.141-146 [in Russian].

Dyal S. 1935. Fauna of Lahore. 4. Spiders of Lahore // Bulletin of the Department of Zoology of the Panjab University. Vol.1. P.119-252.

Hu J.L. 2001. Spiders in Qinghai-Tibet Plateau of China. Henan Science and Technology Publishing House. 658 p.

Lehtinen P.T. 1967. Classification of the Cribellate spiders and some allied families, with notes on the evolution of the suborder Araneomorpha // Annales Zoologici Fennici. Vol.4. No.3. P. $1-468$.

Marusik Y.M., Esyunin S. L., Tuneva T. K. 2015. A survey of Palaearctic Dictynidae (Araneae). 1. Taxonomic notes on Dictynomorpha Spassky, 1939, Brigittea Lehtinen, 1967 and Lathys Simon, 1884 // Zootaxa. Vol.3925. No.1. P.129144.

Marusik Y.M., Koponen S. 1998. New and little known spiders of the subfamily Dictyninae (Araneae: Dictynidae) from south Siberia // Entomological Problems. Vol.29. P.79-86.

Marusik Yu.M., Penney D. 2010. Conformation of the male palp in some spiders belonging to the RTA-clade and problems in taxonomy // Book of Abstracts. 18th International Congress of Arachnology. Siedlce. P.272-276.

Mikhailov K.G. 2013. Spiders (Arachnida: Aranei) of Russia and adjacent countries: a non-annotated checklist // Arthropoda Selecta. Supp1.3. P.1-262.

Ovtchinnikov S.V. 2001. Ecribellate Tricholathys relicta sp.n. (Araneae: Dictynidae: Tricholathysinae) from Kyrghyzstan // Tethys Entomological Research. Vol.3. P.7-10.

Pickard-Cambridge O. 1885. Araneida // Scientific results of the second Yarkand mission. Calcutta. 115 p.

Schenkel E. 1953. Chinesische Arachnoidea aus dem Museum Hoangho-Peiho in Tientsin. // Boletim do Museu Nacional do Rio de Janeiro (N.S., Zool.). Vol.119. P.1-108.

Song D.X. 1987. Spiders from agricultural regions of China (Arachnida: Araneae). Beijing: Agriculture Publishing House. 376 p.

Song D.X., Lu L. 1985. On some dictynids from China (Araneae: Dictynidae) // Sinozoologia. Vol.3. P.77-83.

Song D.X., Wang H.Z., Yang H.F. 1985. On two dictynids from China (Araneae: Dictynidae) // La Animala Mondo. Vol.2. P.23-25.

Spassky S. 1952. [Spiders of Turan Zoogeographical Province] // Entomologicheskoe Obozrenie. Vol.32. P.192-205 [in Russian]. 
WSC. 2016. World Spider Catalog. Natural History Museum Bern, version 17.0. Available from: http://wsc.nmbe.ch (accessed 02 March, 2016).

Yin C.M., Peng X.J., Yan H.M., Bao Y.H., Xu X., Tang G., Zhou Q.S., Liu P. 2012. Fauna Hunan: Araneae in Hunan, China. Changsha: Hunan Science and Technology Press. 1590 p.

Zhang W.S. 1987. Farm spiders from Hebei Province. Hebei: Hebei University of Science and Techology Press. 299 p.
Zhang Z.S., Li S.Q. 2011. On four new canopy spiders of Dictynidae (Araneae) from Xishuangbanna rainforest, China // Zootaxa. Vol.3066. P.21-36.

Zhu M.S., Shi J.G. 1985. Crop field spiders of Shanxi Province. Agriculture Planning Committee of Shanxi Province. 239 p.

Responsible editor D.V. Logunov 